\title{
Characterization of Cornus (Dogwood) Genotypes Using DNA Fingerprinting
}

\author{
John H. Culpepper, Luis A. Sayavedra-Soto, Brant J. Bassam, and Peter M. Gresshoff \\ Plant Molecular Genetics (OHLD), College of Agriculture, University of Tennessee, P. O. Box \\ 1071, Knoxville, TN 37901
}

Additional index words. woody perennials, cultivar identification, RFLP

\begin{abstract}
Several horticulturally important members of the genus Cornus were characterized at the DNA level to identify genotypes. Random genomic DNA fragments from Cornus florida L. 'Barton' were cloned into pBR322 and $\lambda$ Gem-11 and used to search for restriction fragment length polymorphisms (RFLPs) among C. sericea L., C. kousa Hance., and four cultivars of $C$. florida: 'Barton', 'Cherokee Princess', 'Cloud 9', and 'Mary Ellen'. Total DNA from these genotypes was restricted with several endonucleases (of which BamHI, EcoRI, and HindIII were used to search for RFLPs), vacuum-blotted onto nylon membranes, and probed with the $C$. florida 'Barton' DNA clones. RFLPs were common among the Cornus species sericea, kousa, and florida, suggesting considerable DNA sequence divergence at the species level. RFLPs were less common among the cultivars of $C$. florida. These cultivars were selected from a narrow geographical area in North America from nursery-grown trees and exhibit much less DNA sequence divergence.
\end{abstract}

Distinguishing between closely related plant cultivars often is difficult. This is certainly true with many cultivars of the important horticultural dogwood (Cornus florida) tree. Morphological characteristics, such as floral bract shape, floral bract color, and growth habit, are the usual means by which these cultivars are separated. However, some $C$. florida cultivars are so phenotypically similar that identification by observable traits becomes very difficult (Santamour and McArdle, 1985). Due to this phenotypic similarity, confusion exists among persons charged with growing, breeding, marketing, or otherwise identifying specific Cornus cultivars. A more sensitive tool to accurately identify $C$. florida genotypes would, therefore, be of value.

Within the past several years, molecular biological techniques have been applied to the area of plant cultivar identification. One such technique, DNA fingerprinting, which uses analysis of-restriction fragment length polymorphisms (RFLPs), has been particularly useful. Analysis by RFLP has proven to be a very sensitive tool for separating closely related plants. Most of the plants analyzed so far with RFLP technology and DNA fingerprinting have been agronomic and/or herbaceous plants. Some DNA fingerprinting work, however, has been done on woody perennials. In particular, the M13 repeat probe has been used to detect RFLPs in Pinus, Asimina, Populus, and Polyalthia (Rogstad et al., 1988). Variability in plastid DNA has also been used to identify Populus cultivars (Radetzky, 1989) and plastid inheritance in Sequoia (Neal et al., 1989). We are not aware of any reports published on the use of DNA fingerprinting for woody perennial cultivar identification.

In this study we asked whether RFLPs could be used to separate 1) different species of the woody genus Cornus and 2) closely related cultivars of $C$. florida.

\footnotetext{
Received for publication 11 Sept. 1990. We thank Sieglinde Angermüller for her help and advice during the early stages of the project, Debbie Ellis and Janice Crockett for their valuable support throughout this project, and Willard $\mathrm{T}$. Witte for discussion and comments. John Culpepper was a recipient of a Racheff studentship. Mention of a trade name, proprietary product, or specific equipment does not constitute a guarantee or warranty by the Univ. of Tennessee and does not imply approval to the exclusion of other products that may also be suitable. The cost of publishing this paper was defrayed in part by the payment of page charges. Under postal regulations, this paper therefore must be hereby marked advertisement solely to indicate this fact.
}

Materials and Methods

Plant materials and reagents. Plant samples were chosen from newly emerging leaf tissue ( $0.5 \mathrm{~g}$ fresh weight, 5 to $40 \mathrm{~mm}$ long) of six Cornus genotypes (C. f!orida 'Cherokee Princess', 'Barton', 'Mary Ellen', and 'Cloud 9', C. kousa, and C. sericea). Leaf tissue was collected midsummer from trees in the Knoxville, Term., area. Tissue was immediately frozen in liquid nitrogen and either processed the same day or stored at $-70 \mathrm{C}$. Commercially available molecular-grade reagents from Sigma (St. Louis), Bethesda Research Laboratory (Gaithersburg, Md.), and Boehringer Mannheim (Indianapolis) were used.

Nucleic acids isolation. Total genomic DNA was isolated by grinding tissue to a fine powder with a mortar and pestle in the presence of liquid nitrogen and $0.25 \mathrm{~g}$ of insoluble polyvinylpolypyrrolidone (Polyclar AT; Serva, Paramus, N.J.). Extraction buffer ( $15 \mathrm{ml}$ of $100 \mathrm{~mm}$ Tris.HCl, $\mathrm{pH} 8 ; 200 \mathrm{~mm} \mathrm{Na}_{2}$ EDTA, $\mathrm{pH} 8 ; 500 \mathrm{~mm} \mathrm{NaCl} ; 10 \mathrm{~mm} \beta$-mercaptoethanol) was added directly to the cold mortar and frozen. The sample was ground further as it thawed. The extraction mixture was transferred to a 50-ml centrifuge tube containing $1 \mathrm{ml}$ of $20 \%$ sodium dodecyl sulfate (SDS), mixed, and placed for $15 \mathrm{~min}$ in a $65 \mathrm{C}$ water bath. After this, $5 \mathrm{ml}$ of $5 \mathrm{M}$ potassium acetate was added, and the mixture was allowed to stand on ice for $30 \mathrm{~min}$. The sample was then centrifuged for $20 \mathrm{~min}$ at $25,000 \times g$ at $4 C$. The supernatant was filtered into a clean $50-\mathrm{ml}$ centrifuge tube containing $10 \mathrm{ml}$ of ice-cold isopropanol. The two phases were thoroughly mixed by inverting the tube several times and then placed at $-20 \mathrm{C}$ for $30 \mathrm{~min}$. After centrifugation $(15 \mathrm{~min}$ at $20,000 \times g$ ), the supernatant was discarded. The pelleted DNA was partially air-dried and redissolved in $0.7 \mathrm{ml}$ of TE buffer (50 mM Tris $\cdot \mathrm{HCl}, 10 \mathrm{~mm} \mathrm{Na}$ EDTA, pH 8) in a 55C water bath with occasional swirling. The nucleic acids were precipitated with $70 \mu \mathrm{l}$ of $3 \mathrm{M}$ sodium acetate and $1.4 \mathrm{ml}$ of ice-cold ethanol held in a centrifuge tube for $20 \mathrm{~min}$ at $-20 \mathrm{C}$. The nucleic acids were recovered by centrifugation and washed twice with cold $80 \%$ ethanol. The DNA was suspended in $0.1 \mathrm{ml}$ of TE buffer and stored at 4C. Care was taken to avoid shearing of the DNA in all steps.

Restriction enzymes, reactions, and electrophoresis. Restriction enzymes were used according to the direction of the manufacturer (United States Biochemical, Cleveland; Bethesda Research Laboratories, Boehringer Mannheim). Plant DNA 
samples were digested with 5 units of restriction endonuclease per microgram of DNA. Samples were assumed to be completely digested by comparing them to undigested DNA and to banding patterns in an agarose gel. Nucleic acid concentration was determined by its absorbance at $260 \mathrm{~nm}$ and by running sample gels. Digestion of the DNA was performed with various endonucleases (BamHI, EcoRI, HindIII, KpnI, PstI, SalI, SmaI, SstI, SphI, and XbaI) with and without prior treatment with proteinase $\mathrm{K}$. The addition of proteinase $\mathrm{K}$ before digestion was tested but was found to have no effect on digestion and, therefore, was not used. Digests of the DNA samples $(\approx 5 \mu \mathrm{g}$ per sample) were loaded on $0.75 \%$ to $1 \%$ agarose gels and subjected to electrophoresis at $4 \mathrm{~V} \cdot \mathrm{cm}^{-1}$ in Tris-acetate buffer $(0.04 \mathrm{M}$ Tris-acetate and $0.001 \mathrm{M} \mathrm{Na}_{2}$ EDTA, $\mathrm{pH} 8$ ). Nucleic acids were visualized by staining the gels with ethidium bromide (100 $\left.\mu \mathrm{g} \cdot \mathrm{liter}^{-1}\right)$. Occasionally, samples were difficult to digest. By adding $10 \mu \mathrm{l}$ of $0.1 \mathrm{~m}$ spermidine to the entire DNA preparation, samples could be digested in $\approx 4 \mathrm{~h}$.

Generation of genomic probes and labeling. Two libraries of different insert size were generated by "shotgun" cloning into a plasmid and into a h-vector, thus offering a wide selection of sizes (from 300 to 23,000 base pair). Random genomic clones were generated from $C$. florida 'Barton' DNA digested with BamHI endonuclease and cloned into the pBR322 vector (pUTC for plasmid Univ. of Tennessee Cornus). Ligated insert-plasmid vector DNA was introduced to Escherichia coli strain HB101 by transformation with $0.5 \mathrm{M} \mathrm{CaCl}_{2}$. Transformants were isolated in ampicillin Luria-Bertani agar plates and screened for inserts by their sensitivity to tetracycline (Maniatis et al., 1982). Plasmid isolation was by alkaline lysis (Maniatis et al., 1982). Excised fragments were isolated and purified by electroelution (Maniatis et al., 1982).

DNA $\lambda$ clones were produced by cloning total genomic DNA from C. florida 'Barton' partially digested with MboI, and ligated into the BamHI site of $\lambda$ GEM-11 vector (Promega, Madison, Wis.) and coded $\lambda$ UTC. Ligated insert-h vector was packaged in vitro, absorbed into E. coli strain LE392, and spread onto phage-agar plates (Maniatis et al., 1982). The $\lambda$ UTC clones were isolated by lysis as described (Chisholm, 1989). The inserts were excised from the vector using SalI, yielding one to 10 fragments per clone. Individual $\lambda$ UTC fragments were subsequently isolated and used as probes for additional experiments. A total of 14 Cornus DNA probes in conjunction with three restriction endonucleases (HindIII, EcoRI, and BamHI) were used to search for RFLPs among the six Cornus genotypes. Probe DNA was radioactively labeled with $\left[\alpha^{32} \mathrm{P}\right]$-deoxycytidine triphosphate (New England Nuclear, Beverly, Mass.) with a random primer labeling kit (Boehringer Mannheim) to a specific activity of 1 to $4 \times 10^{8} \mathrm{dpm} / \mu \mathrm{g}$ DNA.

Transfers and hybridization of DNA. DNA was alkalinetransferred (Hicks and Vecoli, 1987) to Hybond-N (Amersham, Arlington Heights, 111.) or Zeta-Probe (Bio-Rad, Hercules, Calif.) at the hybridization temperature with $0.1 \times \mathrm{SSPE}, 1 \%$ SDS Autoradiography was carried out for 1 to 8 days at $-70 \mathrm{C}$ with X-OMAT AR film (Eastman Kodak, Rochester, N.Y.) and intensifying screens.

Filters were stripped and reprobed up to five times by washing the filters in $5 \mathrm{~mm}$ Tris. $\mathrm{HCl}, 0.2 \mathrm{~mm}$ NaEDTA, $0.1 \times$ Denhardt's solution, and $0.05 \% \mathrm{NaH}_{2} \mathrm{PO}_{4}(\mathrm{pH} 8)$ for 1 to 3 hat 70 to $75 \mathrm{C}$. Membranes were exposed for 5 days to check for residual radioactivity.

\section{Results and Discussion}

DNA. isolation and restrictability. Several difficulties that seem to be common to many woody perennials had to be overcome.
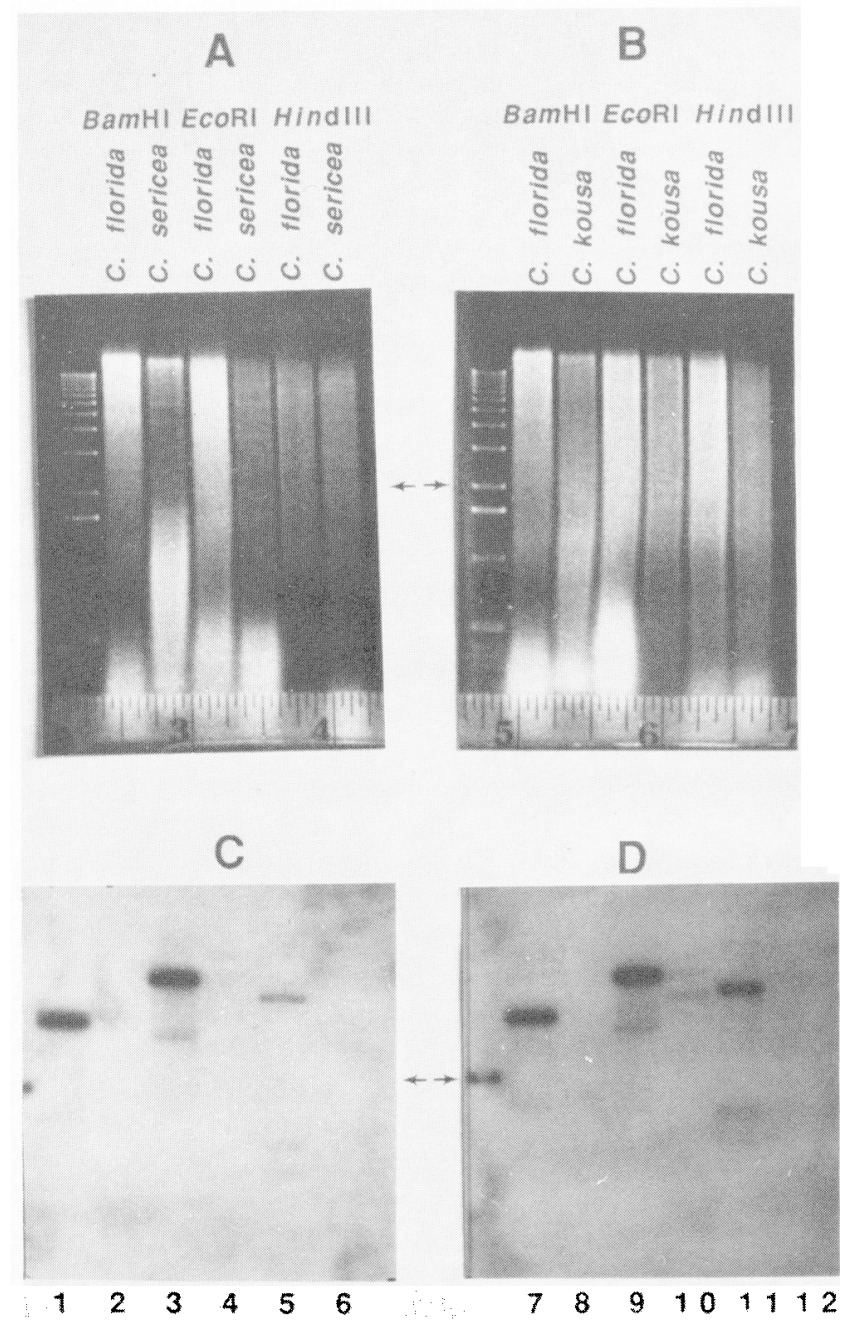

Fig. 1. Confirmation of restriction digests and hybridization of three Cornus species produced with pUTC10. (A) DNA of C. florida 


\begin{tabular}{|c|c|c|c|c|c|}
\hline & C. kousa & C. sericea & $\begin{array}{l}\text { C. florida } \\
\text { 'Barton' }\end{array}$ & $\begin{array}{l}\text { C. florida } \\
\text { 'Cherokee } \\
\text { Princess' }\end{array}$ & $\begin{array}{l}\text { C. florida } \\
\text { 'Cloud } 9 \text { ' }\end{array}$ \\
\hline C. sericea & $\left.\begin{array}{l}\text { BamHI } \\
\text { EcoRI }\end{array}\right\}_{\mathrm{pUTC} 10^{\mathrm{x}}}$ & & \multirow[b]{2}{*}{. } & & \multirow{3}{*}{. } \\
\hline $\begin{array}{l}\text { C. florida } \\
\text { 'Barton' }\end{array}$ & 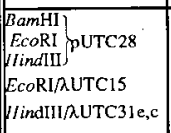 & & & & \\
\hline $\begin{array}{l}\text { C. florida } \\
\text { Cherokec } \\
\text { Princess' }\end{array}$ & 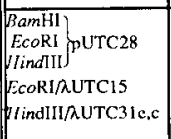 & & 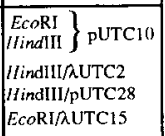 & & \\
\hline $\begin{array}{l}\text { C.florida } \\
\text { 'Cloud } 99\end{array}$ & /IindIIIAUTC31e,c & & & & \\
\hline $\begin{array}{l}\text { C. florida } \\
\text { 'Mary Ellen' } \\
\text {. }\end{array}$ & 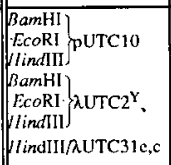 & BamHI/pUTC10 & 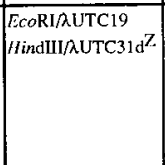 & \begin{tabular}{|l|} 
EcoRI//AUTC19 \\
HindII/AUTC31
\end{tabular} & $\begin{array}{l}\text { oR1/AUTC19 } \\
\text { indIII/AUTC31 }\end{array}$ \\
\hline
\end{tabular}

Fig. 2. Restriction enzyme/DNA probe combinations that produced distinguishing RFLPs between Cornus genotypes. Genomic DNA and probes were prepared as outlined in Materials and Methods.

${ }^{2}$ Lowercase letters indicate the fragment of the $\lambda$ UTC clone referred

'Hybridization signal was very weak and, therefore, this result is variable

${ }^{x} \lambda$ UTC DNA clones not given a letter code means that the whole DNA clone was used as a probe.

Total genomic DNA from several Cornus genotypes could be isolated in $\approx 4 \mathrm{~h}$. The method required standard laboratory equipment and no isopycnic centrifugation. Leaves longer than $4 \mathrm{~cm}$ contained high polysaccharide and polyphenolic contamination and yielded low concentration of DNA ( 25 to $50 \mu \mathrm{g} \cdot \mathrm{g}^{-1}$ fresh weight tissue). By using younger, smaller leaves and adding Polyclar AT during grinding, DNA yield was increased to 250 to $500 \mu \mathrm{g} \cdot \mathrm{g}^{-1}$ fresh weight tissue, and the polyphenolic contamination was eliminated. Polysaccharide contamination was reduced but not eliminated. We frequently observed that polysaccharide contamination resulted in sample loss when samples were loaded into the agarose submarine gels. (DNA samples would rapidly eject into the running buffer.) Because of this problem, samples were loaded into gel wells and then capped with agarose as described (Culpepper et al., 1990). By so doing, minor polysaccharide contamination could be tolerated.

Endonucleases with six base pair recognition sites showed various restriction profiles. For example, the enzymes BamHI, EcoRI, and HindIII consistently yielded DNA fragments spread evenly under $20 \mathrm{~kb}$ in size for the six Cornus genotypes used. Enzymes producing fragments mostly under the $20-\mathrm{kb}$ range were chosen for this study. However, the enzymes KpnI and PstI yielded mostly fragments of $20 \mathrm{~kb}$ and larger, which were difficult to resolve by agarose electrophoresis. We also had dif-

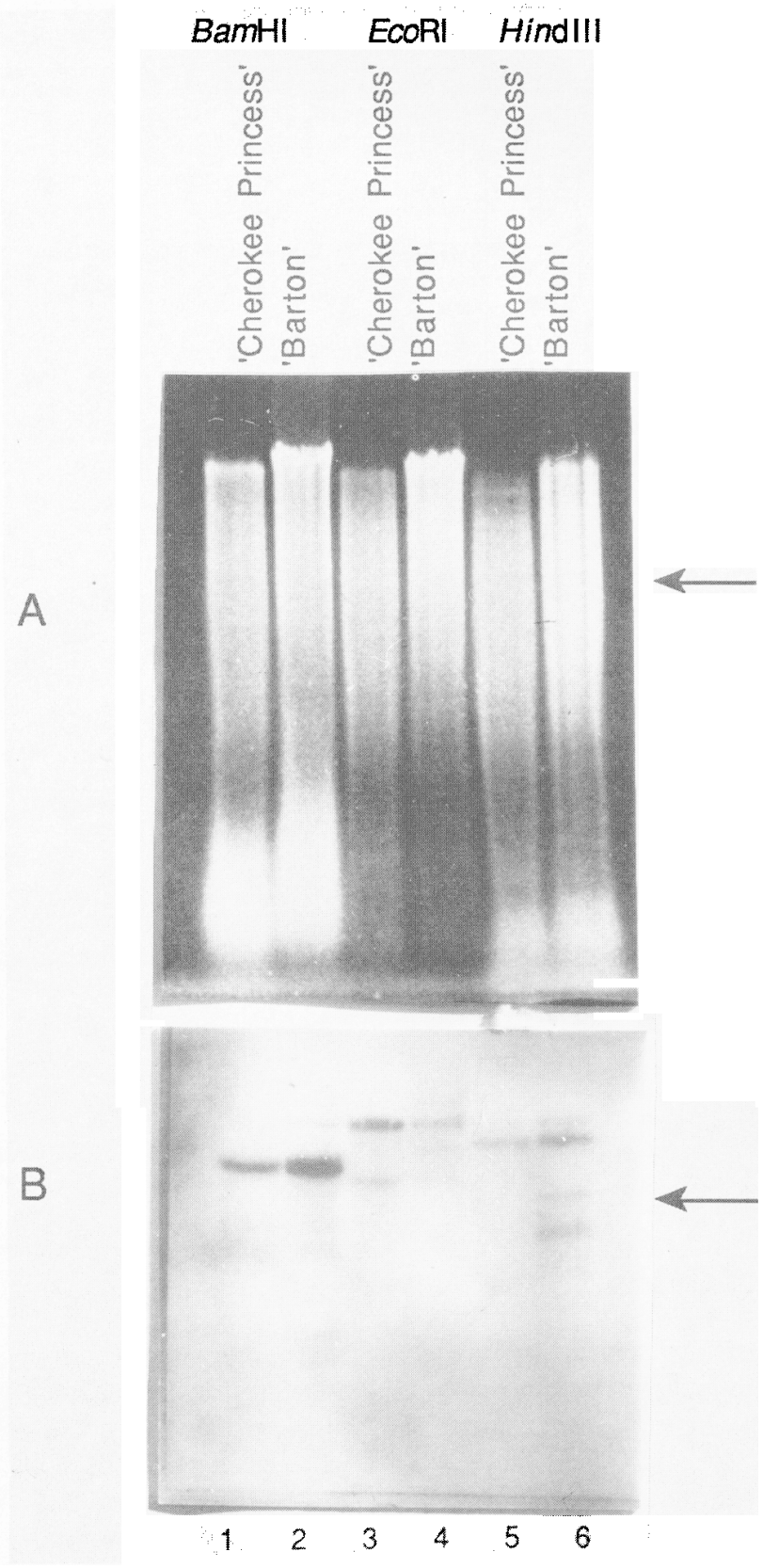

Fig. 3. Confirmation of restriction digests and autoradiographs of Cornus florida cultivars Cherokee Princess and Barton produced with pUTC10. (A) Genomic DNA of $C$. florida 'Cherokee Princess' and C. florida 'Barton' ( $\approx 5 \mu \mathrm{g} / \mathrm{lane})$ restricted with BamHI, EcoRI, and HindIII. (B) Autoradiograph of gel in A showing an RFLP between these two $C$. florida cultivars (lanes 5 and 6). Autoradiographs were exposed 8 days. The membrane used was Zeta-Probe. Arrows indicate fragments corresponding to $\approx 2 \mathrm{~kb}$ in size. 


\begin{tabular}{|c|c|c|c|c|}
\hline & C. kousa & $\begin{array}{l}\text { C. florida } \\
\text { 'Barton' }\end{array}$ & $\begin{array}{c}\text { C.florida } \\
\text { Cherokee Princess' }\end{array}$ & $\begin{array}{l}\text { C. florida } \\
\text { 'Cloud 9' }\end{array}$ \\
\hline \multicolumn{5}{|l|}{ C. sericea } \\
\hline $\begin{array}{l}\text { C. florida } \\
\text { 'Barton' }\end{array}$ & $\left\{\begin{array}{l}\text { BamHII } \\
\text { HindII }\end{array}\right\} \lambda \mathrm{UTC} 15^{\mathrm{x}}$ & & & \multirow[t]{3}{*}{. } \\
\hline $\begin{array}{l}\text { C. florida } \\
\text { Cherokee } \\
\text { Princess' }\end{array}$ & $\begin{array}{l}\text { BamHI } \\
\text { HindIII }\} \lambda U T C 15 \\
.\end{array}$ & 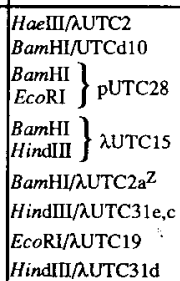 & & \\
\hline $\begin{array}{l}\text { C. florida } \\
\text { 'Cloud 9' }\end{array}$ & $\because$ & 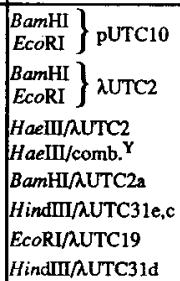 & 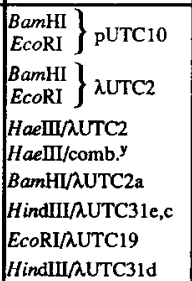 & \\
\hline $\begin{array}{l}\text { C. florida } \\
\text { 'Mary Ellen' }\end{array}$ & & 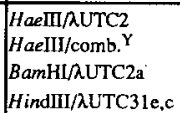 & 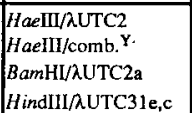 & 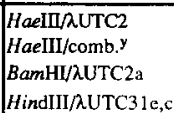 \\
\hline
\end{tabular}

Fig. 4. Restriction enzyme/DNA probe combinations that produced identical banding patterns between Cornus genotypes. Genomic DNA and probes were prepared as outlined in Materials and Methods.

${ }^{2}$ Lowercase letters indicate fragments of the $\lambda$ UTC clone referred to.

${ }^{y}$ This was an equal molar mixture of probes $\lambda \mathrm{UTC} 2 \mathrm{~b}, \lambda \mathrm{UTC} 5 \mathrm{~d}$, $\lambda$ UTC15c, $\lambda$ UTC15f, and $\lambda$ UTC31c.

${ }^{x} \lambda$ UTC DNA clones not given a letter code means that the whole DNA clone was used as a probe.

six base recognition site endonucleases), revealing the arms of sizes -20 and $9 \mathrm{~kb}$ and the several Cornus inserts generated. When SalI was used, two pieces of the vector $(\approx 100$ bases long $)$ were included within the dogwood DNA and showed no effect in the hybridization patterns. The dogwood DNA fragment from $\lambda$ UTC19 was also isolated from a Sall digest, purified, and used as a probe onto EcoRI-cut DNA from four $C$. florida cultivars. This procedure was performed to compare the Zeta-Probe vs. the Hybond-N membranes. Although no RFLP was observed with this probe-enzyme combination, clearer hybridization signals were obtained with the Zeta-Probe membrane (data not shown). Probes made of individual dogwood fragments also produced stronger hybridization signals because of the relative specific activity increase.

RFLPs found among Cornus species. The Cornus DNA probes produced hybridization signals of varying intensity among the species tested. This result was expected since all of these cultivars were selected less than 35 years ago from $C$. florida trees within a small geographic area and probably have limited genetic diversity. Enzyme-probe combinations produced from two to 10 observable bands on autoradiographs for each genotype. In more than $95 \%$ of the cases, bands were identical between the $C$. florida cultivars tested (Fig. 4). Weak hybridization signals were consistently observed when these same $C$. florida probes were hybridized to C. kousa DNA (Fig. 1), implying DNA differences between $C$. florida and C. kousa for these DNA probes.

RFLPs were common between C. kousa and the four cultivars of $C$. florida when probed with $C$. florida DNA probes (Fig. 2). Cornus florida -derived probes hybridized weakly to C. sericea. The restriction pattern for C. florida 'Cherokee Princess' was reproduced twice in Fig. 1 and once in Fig. 3 for the BamHI, EcoRI, and HindIII/pUTC10 enzyme-probe combinations. Several bands were missing in the HindIII digest of 'Cherokee Princess' DNA when compared to the HindIII digest of 'Barton' DNA (Fig. 3).

Several important morphological characteristics are used to differentiate taxonomically members of the Cornus genus (Table 1). Some important characteristics are shared by C. kousa and C. florida (although they are from widely separated geographical areas), whereas $C$. sericea differs from both $C$. florida and C. kousa phenotypically (Table 1). The hybridization data showed differences among species and among cultivars (Figs. 1 and 3).

RFLPs found among cultivars of C. florida. An example of an RFLP obtained between the $C$. florida cultivars Cherokee Princess and Barton is shown in Fig. 3. The HindIII digests probed with pUTC10 produced four clear bands in the $C$. florida 'Barton' lane but only three bands in the $C$. florida 'Cherokee Princess' lane. Most of the Cornus DNA probes produced identical banding patterns among the four $C$. florida cultivars studied. Strong and consistent hybridization signals were observed for every $C$. florida 'Barton'-derived clone when hybridized to the $C$. florida cultivars Barton, Cherokee Princess, Mary Ellen, and Cloud 9. This result suggests limited variability at the DNA level and was expected due to the close taxonomic relationship among these cultivars (Santamour and McArdle, 1985). The intraspecies data coupled with inter-

Table 1. Taxonomic considerations of Cornus spp. and C. florida cultivars.,

\begin{tabular}{|c|c|c|c|c|c|c|c|}
\hline Genotype & $\begin{array}{l}\text { Fruit } \\
\text { group }\end{array}$ & $\begin{array}{l}\text { Iridoid } \\
\text { glucosides }\end{array}$ & $\begin{array}{c}\text { Floral } \\
\text { type }\end{array}$ & $\begin{array}{c}\text { Bloom } \\
\text { time }\end{array}$ & $\mathrm{n}^{\mathrm{x}}$ & $\begin{array}{c}\text { Indigenous geographical } \\
\text { distribution }\end{array}$ & $\begin{array}{c}\text { Original } C \text {. florida cultivar } \\
\text { selection site }\end{array}$ \\
\hline \multicolumn{8}{|l|}{ C. florida } \\
\hline Cherokee Princess & Red & Yes & Large-bracted & Before leaves & 11 & Eastern North America & Mayfield, Ken. \\
\hline Barton & Red & Yes & Large-bracted & Before leaves & 11 & Eastern North America & Birmingham, Ala. \\
\hline Mary Ellen & Red & Yes & Large-bracted & Before leaves & 11 & Eastern North America & Winchester, Term. \\
\hline Cloud 9 & Red & Yes & Large-bracted & Before leaves & 11 & Southeastern North America & Huntsville, Ala. \\
\hline C. kousa & Red & Yes & Large-bracted & After leaves & 11 & Asia & \\
\hline C. sericea & Blue & No & Small-bracted & After leaves & 11 & North America & \\
\hline
\end{tabular}

${ }^{2}$ Derived from Dermen (1932), Eyde (1988), and Neal et al. (1989).

${ }^{y}$ Shown are the major biochemical and morphological characteristics used to separate members of the genus Cornus. Added also are the geographical distributions of the Cornus spp. under study and the sites in North America where the original trees of C. florida 'Barton', 'Cherokee Princess', and 'Mary Ellen' were located. These cultivars have been vegetatively maintained within the nursery industry since the original cuttings were taken.

${ }^{x}$ Haploid chromosome number. 
species data suggest a high degree of germplasm diversity at the genus level but a low degree of germplasm diversity at the $C$. florida cultivar level, which is in agreement with taxonomic considerations (Table 1).

RFLPs among C. florida 'Barton', 'Cherokee Princess', 'Cloud 9', and 'Mary Ellen' were found with 11 out of 52 DNA probeenzyme combinations (Fig. 2). The actual number of bands establishing RFLPs, however, was low $(<5 \%)$. In other systems (plant and animal), this high degree of band sharing is common between related individuals when random, genomic, homologous DNA probes are used (Helentjaris et al., 1986; Schumm et al., 1988).

In conclusion, we have demonstrated that closely related C. florida cultivars can be identified using RFLP technology. This technology can be applied immediately to $C$. florida cultivar identification and, perhaps, to the Cornus taxonomy. Additionally, and perhaps more importantly, we have shown the first step in the molecular characterization of Cornus.

\section{Literature Cited}

Chisholm, D. 1989. A convenient moderate-scale procedure for obtaining DNA from bacteriophage lambda. Biotechnology 7:21-23.

Culpepper, J. H., S.A. Angermüller, and L.A. Sayavedra-Soto. 1990 Avoiding woody plant DNA sample loss when loading submarine agarose gels for electrophoresis. Biotechnology 8: 171-172.

Dermen, H. 1932. Cytological studies of Cornus. J. Arnold Arboretum 13:410-417.
Eyde, R.H. 1988. Comprehending Cornus. Puzzles and progress in the systematic of the dogwoods. Bet. Rev. 54:233-351.

Helentjaris, I., M. Slocum, S. Wright, A. Schaefer, and J. Nienhuis. 1986. Construction of genetic linkage maps in maize and tomato using restriction fragment length polymorphisms. Theor. Applied Genet. 72:761-769.

Hicks, D.A. and C. Vecoli. 1987. The use of a PVDF membrane in the alkaline transfer of DNA. Biotechnology 5:206-208.

Kessler, C. and H.J. Holtke. 1986. Specificity of endonucleases and methylases. A review. Gene 47:1-153.

Maniatis, T., E.F. Fritsch, and J. Sambrook. 1982. Molecular cloning (A laboratory manual). Cold Spring Harbor Press, New York.

Neal, D. B., K.A. Marshall, and R.R. Sederoff. 1989. Chloroplast and mitochondrial DNA are paternally inherited in Sequoia sempervirens D. Don Endl. Proc. Natl. Acad. Sci. USA 86:9347-9349.

Radetzly, R. 1989. Genetic studies on poplar clones: Investigation of mitochondrial DNA. Proc. Intl. Conf. Fast-growing Trees and Nitrogen-fixing Trees, 8-12 Oct. 1989, Marburg, Germany. p. 50. (Abstr.)

Rogstad, S. H., J. C. Patton, and B.A. Schaal. 1988. M13 repeat probe detects DNA minisatellite-like sequences in gymnosperm and angiosperms. Proc. Natl. Acad. Sci. USA. 85:9176-9178.

Santamour, F.S. and A.J. McArdle. 1985. Cultivar checklists of the large-bracted dogwoods: Cornus florida, C. kousa, and C. nuttallii. J. Arboriculture 11:29-36.

Schumm, J. W., R.G. Knowlton, J.C. Braman, D.F. Barker, D. Botstein, G. Akots, V.A. Brown, T.C. Gravius, C. Helms, K. Hsiao, K. Redike, J.G. Thurston, and H. Donis-Keller. 1988. Identification of more than 500 RFLPs by screening random genomic clones. Amer. J. Human Genet. 42:143-159. 